\title{
The role of land administration in the accession of Central European countries to the European Union
}

\author{
Theo Bogaerts ${ }^{\mathrm{a}}$, Ian P. Williamson ${ }^{\mathrm{a}, \mathrm{b}, *}$, Elfriede M. Fendel ${ }^{\mathrm{a}}$ \\ ${ }^{a}$ Department of Geodesy, Delft University of Technology, The Netherlands \\ ${ }^{\mathrm{b}}$ Department of Geomatics, University of Melbourne, Melbourne, VIC 3010, Australia
}

Received 9 February 2001; received in revised form 7 July 2001; accepted 20 July 2001

\begin{abstract}
One of the key requirements of the European Union (EU) for accession of Central European countries (CEC) to the EU is the establishment of free market economies which parallel the economies in Western Europe based on the adoption of the Acquis Communautaire (Acquis) from the EU. Central to this objective is the privatisation of lands and the establishment of efficient land markets. To this end the EU and many other countries and international organisations have committed significant resources to support land administration, and particularly cadastral projects, in Central Europe since 1992.

This paper reviews the role that the establishment of land administration systems is playing in the accession of CEC to the EU. Other key requirements for accession to the EU are the adoption of the Common Agricultural Policy, the protection of human rights, environmental sustainability and institution building. The paper also considers the role that land administration plays in supporting these objectives and develops a generic framework for land administration projects in support of accession to the EU.

As background the paper uses examples to highlight the historical context of land, the evolution of land administration in Central Europe, the reconstruction of property rights and the justification of land administration projects in the context of AGENDA 2000 for a wider Europe. The paper provides an international context by examining land administration trends globally.

The paper concludes by highlighting the challenges facing the establishment of land administration systems in CEC. (C) 2002 Elsevier Science Ltd. All rights reserved.
\end{abstract}

Keywords: Land administration; European Union (EU); Central European countries (CEC); Cadastre; Accession; Sustainable development

\section{Introduction}

On July 16, 1997 the Commission of the European Union (EU) presented its communication "AGENDA 2000: for a Stronger and Wider Europe" (EU, 1997), together with Opinions on each of the applications of 10 Central European countries (CES) (Fig. 1) (besides these countries Cyprus, Malta and Turkey have also applied for membership of the EU). In a single framework, the Commission outlined a broad framework for the development of the EU and its policies beyond the turn of the century, the impact of the enlargement on the EU as a whole and the future financial framework beyond 2000, taking account of an enlarged Union. Enlargement represents a historic turning point for Europe, an

*Corresponding author. Department of Geomatics, University of Melbourne, Melbourne, VIC 3010, Australia. Tel.: +61-3-8344-4431; fax: + 61-3-9347-4128.

E-mail address: ianpw@unimelb.edu.au (I.P. Williamson). opportunity which it must seize for the sake of its security, its economy, its culture and its status in the world.

In assessing applications from countries for membership of the EU, the Union monitored the development of the countries using the EU membership criteria laid down by the Copenhagen European Council in June 1993 and the EU principles set down the Acquis Communautaire 1 (the "rules" of the EU):

- the applicant country must have achieved stability of institutions guaranteeing democracy, the rule of law,

\footnotetext{
${ }^{1}$ The 'Acquis Communautaire' (Source: http://europa.eu.int/comm/ enlargement/pas/phare/wip/acquis.htm)

The 'Acquis Communautaire' comprises the entire body of legislation of the European Communities which has accumulated, and been revised, over the last 40 years. It includes:

- the founding Treaty of Rome as revised by the Maastricht and Amsterdam Treaties;

- the Regulations and Directives passed by the Council of Ministers, most of which concern the single market;

- the judgements of the European Court of Justice.
} 
human rights and respect for and protection of minorities:

- it must have a functioning market economy, as well as the capacity to cope with competitive pressure and market forces within the EU; and

- it must have the ability to take on the obligations of membership, including adherence to the aims of political, economic and monetary union.

At the Nice European Council in December 7-9, 2000, a timetable has been set for the countries, which are shown in Fig. 1. At the earliest the countries can enter the EU in 2003 if they meet the criteria. In quarterly reports, "The Opinions", the EU reports about the progress of every country towards meeting the criteria.

As stated above, a central requirement for membership of EU is the existence of a functioning market economy. A key requirement of a functioning market economy is a functioning land market which in turn requires a whole range of legal, institutional, technical and capacity building initiatives (Baldwin et al., 1999; Dale and Baldwin, 1999; Dale, 2000). This requirement has meant that all countries wishing to enter the EU in the foreseeable future, and particularly the CEC, have undertaken major reforms of their land administration systems. These reforms have been strongly supported by the EU through such programmes as PHARE. ${ }^{2}$ Today,

\section{footnote continued}

The 'acquis' has expanded considerably over recent years, and now includes the Common Foreign and Security Policy and justice and home affairs, as well as the objectives and realisation of political, economic and monetary union. Countries wishing to join the EU must adopt and implement the entire 'acquis' upon accession. The European Council has ruled out any partial adoption of the 'acquis', as it is felt that this would raise more problems than it would solve, and would result in a watering down of the 'acquis' itself.

In addition to transposing the body of EU legislation into their own national law, candidate countries must ensure that it is properly implemented and enforced. This may mean that administrative structures need to be set up or modernised, legal systems need to be reformed, and civil servants and members of the judiciary need to be trained.

${ }^{2}$ The PHARE Programme (Source: http://europa.eu.int/comm/ enlargement/pas/phare.htm).

PHARE is currently the main channel for the European Union's financial and technical cooperation with the countries of Central and Eastern Europe (CEECs). It is an abbreviation for Poland and Hungary Action for the Restructuring of the Economy. Set up in 1989 to support economic and political transition, PHARE had by 1996 been extended to include 13 partner countries from the region. Originally allocated Euro 4.2 billion for the 1990-1994 period, the PHARE budget was increased to Euro 6.693 billion for the 1995-1999 period. In Agenda 2000, the European Commission proposed to focus the PHARE Programme on preparing the candidate countries for EU membership by concentrating its support on two crucial priorities in the adoption of the Acquis Communautaire: institution building and investment support. Institution building means adapting and strengthening democratic institutions, public administration and organisations that have a responsibility in implementing and enforcing Community legislation. The integration process is not simply a question of

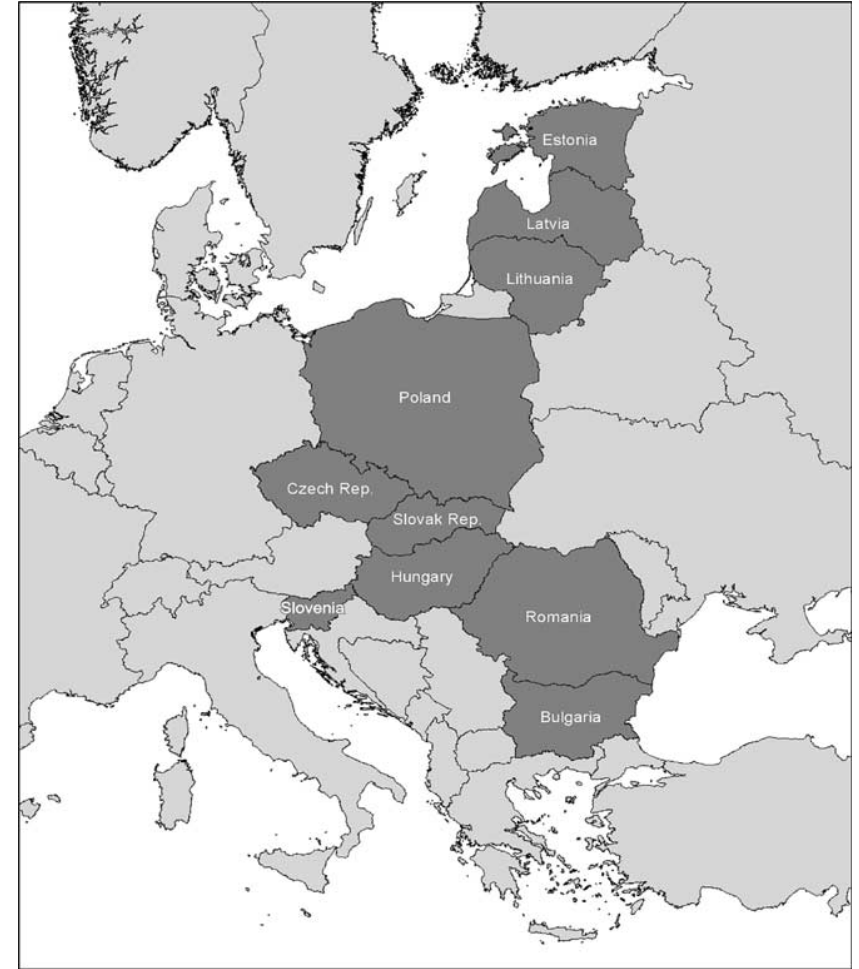

Fig. 1. Candidate member states in Central Europe.

every CEC has a range of land administration reforms underway with a specific focus on cadastral reform activities. The PHARE projects vary from supplying land surveying and photogrammetric equipment, aerial photography, computerisation of Cadastral Offices, the introduction of geographic information systems (GIS) and training programmes.

To support these land administration reforms and in recognition of the importance of land administration, the United Nations established a Meeting of Officials of Land Administration (MOLA) within the UN Economic Commission for Europe (UNECE). As land administration reform has become a key activity within countries seeking accession to the EU, as well as throughout all Europe, MOLA was upgraded and institutionalised in early 1999 as a UN Working Party and is now referred to as the UNECE Working Party on Land Administration (WPLA). MOLA prepared Land Administration Guidelines to assist countries wishing to

\section{footnote continued}

approximating candidate countries' legislation to that of the Community; it is also one of ensuring the effective and efficient implementation of the texts. It includes the development of relevant structures, human resources and management skills. Institution building means training and equipping a wide range of civil servants, public officials, professionals and relevant private sector actors: from judges and financial controllers to environmental inspectors and statisticians, to name but a few. Approximately $30 \%$ of PHARE will be used to meet these institution building needs, in accordance with the conclusions of the Luxembourg European Council, in particular through the Twinning mechanism. 
join the EU to establish land administration systems (UNECE, 1996).

In summary, the objective of this paper is to review the role that land administration, and particularly cadastral reform, plays in the accession of CEC to the EU. The paper commences with a brief review of the rules (Acquis Communautaire) and activities of the EU (PHARE) with regard to the accession of CEC. The paper then uses a number of examples to highlight the historical context of land in Central Europe and argues that without understanding this historical context it is impossible to understand the challenges facing land administration reform in CEC. This is followed by a brief overview of the reconstruction of property rights in Central Europe. The paper focuses on Poland, Czech Republic, Slovak Republic and Hungary since these countries highlight the three generic privatisation processes in CEC: Poland (selling land to individuals), Czech Republic/Slovak Republic (reconstruction of property rights as they were 50 years ago) and Hungary (compensation). The paper then steps back and considers the evolution, trends and justification of land administration systems globally, with particular emphasis on Europe. It shows that the development of modern land administration infrastructures also support environmental and social objectives as well as economic or land market objectives. In this context, an in-depth review is made of the justification for land administration reform in CEC in the context of the Acquis Communautaire rules. A practical framework for the justification and design of land administration projects in CEC in support of accession is developed. The paper concludes by looking at some of the future land administration challenges that will face the soon to be admitted CEC, as well as those in some of the existing EU countries such as Greece and Portugal.

Within this paper the authors refer to the generic term of land administration as the process of determining, recording and disseminating information about the tenure, value and use of land when implementing land management policies (UNECE, 1996). It is considered to include land registration, cadastral surveying and mapping, fiscal, legal and multi-purpose cadastres and parcel based land information systems, and in many systems information supporting land use planning and valuation/land taxation systems. A cadastre is the core or basis of a land administration system and is defined as a parcel based and up-to-date land information system containing a record of interests in land (e.g. rights, restrictions and responsibilities). It usually includes a geometric description of land parcels linked to other records describing the nature of the interests, and ownership or control of those interests, and often the value of the parcel and its improvements (FIG, 1995). This definition of cadastre includes the role of title registers (or Grundbuch) which places equal emphasis on the technical and legal components. The paper places considerable emphasis on cadastral reform, since without the establishment of an effective cadastre, the establishment of modern land administration systems is not possible.

\section{The historical context of land in Central Europe}

It is very difficult, if not impossible, to undertake land administration reform in the CEC without some understanding of the dramatic political changes that have swept the region during this period. These changes have included major land reforms, two world wars, the introduction and collapse of command economies, and the introduction of modern market economies. Land administration reform is intimately tied to issues of justice and the restitution of rights resulting from these changes, not only in the populations within the specific CEC but also countries which were affected by the dispossession and transmigration of millions of people during the period. This turbulent history of the region has greatly influenced today's land administration systems, and particularly their cadastral systems, and continues to have a significant impact on the accession of CEC to the EU. The following historical insight of these developments are drawn heavily on a paper by Bogaerts (1997). The basis for this paper is the regular Strategic Review Studies undertaken by Bogaerts in different countries on behalf of the EU (1992-1998). Importantly, this review is indicative and does not purport to provide a detailed overview of the historical developments in all CEC.

During this century four big political events took place, resulting in changes to the boundaries of different countries, in large transmigrations of people and in major land reforms. These reforms were imposed on and complicated by the gradual evolution of the European land systems as they moved from feudal economies to market economies and as they evolved in response to the Industrial Revolution. These major events were:

- World War I;

- World War II;

- the introduction of centrally planned or demand economies by communist regimes; and

- the collapse of the demand economies and the introduction of free market economies.

\section{The effects of World War I}

World War I had a dramatic impact on Central Europe as outlined above. It was also a catalyst for land reform. Examples of the consequences are described below. 


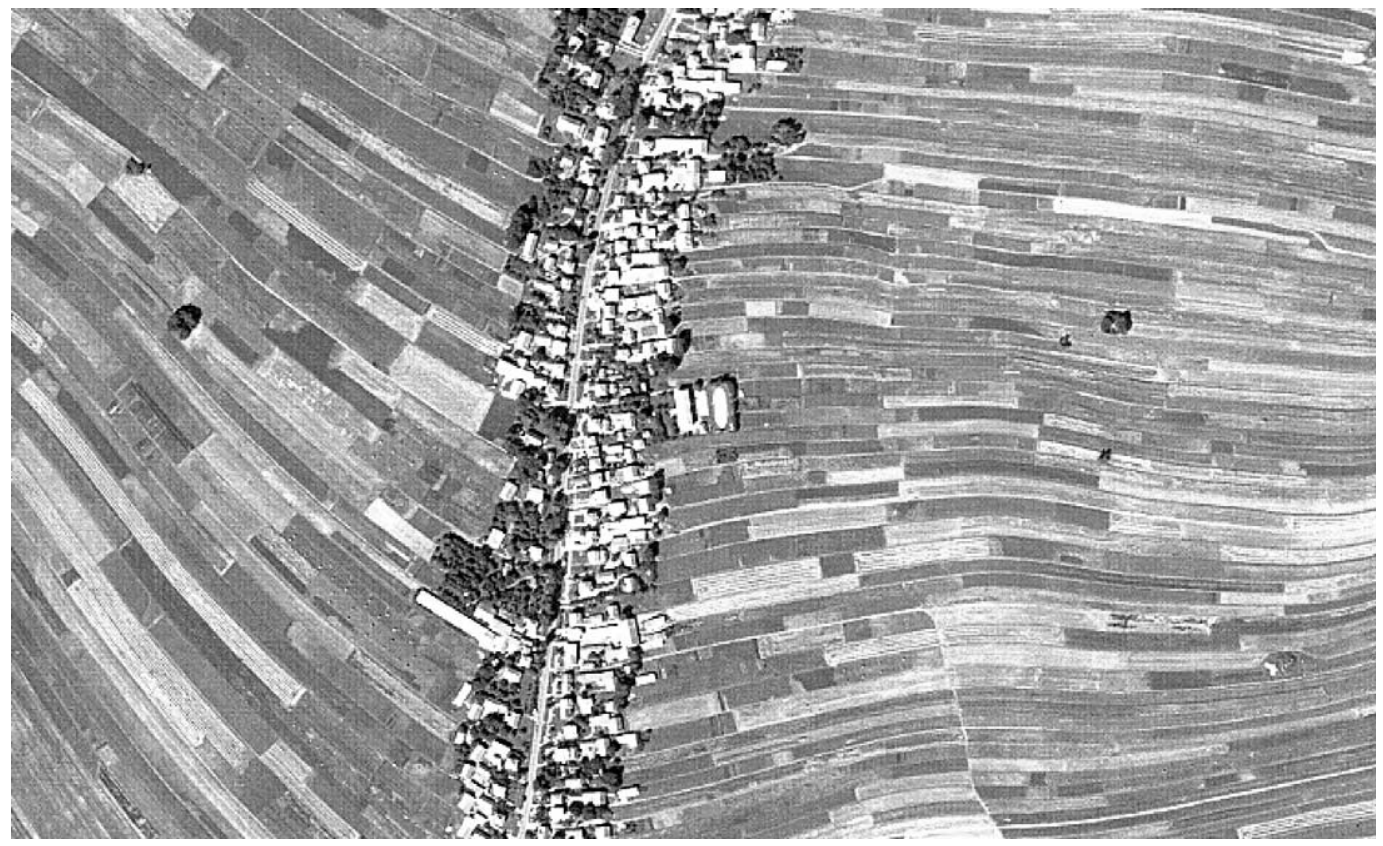

Fig. 2. The rural Polish cadastral framework showing parcel fragmentation.

After World War I, Poland appeared as an independent country on the European map. It was situated more eastward than its present location. The Polish fight for freedom during a period of more than one century was also a fight from Polish farmers to have private properties. The result was that the farmers got one or more small pieces of land (Fig. 2). This struggle for private land has significantly affected the development and operation of land administration systems to this day.

In 1918, Czechoslovakia was established. A large land reform took place according to the Expropriation Act in 1919. Properties of more than 150 ha of agricultural land or more than a total of 250 ha were expropriated. According to a 1920 law the confiscated land was given to municipalities, to private persons and to organisations. Private persons got properties between 6 and 10 ha.

In Hungary, the first land reform in 1920 made an attempt to change the feudal system of large estates by allocating parcels to poor hired labourers and holders of the so-called dwarf parcels. 570,000 ha were divided among 411,000 claimants. The average size of these parcels was between 0.5 and 1 ha. However since these parcels were too small to be economically viable, the new owners had no other choice than to continue to do paid work as they had in the past.

\section{The effects of World War II}

World War II had an equally dramatic affect on land administration in Central Europe. As an example the situation in Poland is described.
The end of World War II resulted in territorial changes for Poland. The nation's total area was decreased by $75,000 \mathrm{~km}^{2}$, and the border was moved to include western and northern territories. Although cadastral documents were available in these areas, the enormous transmigration of people as a result of the war made these documents almost useless. This incomplete and to a large extent out of date cadastral data, including undocumented ownership's statements, statistical data and 'social classification data', was used to institute the so-called simplified land cadastre at the beginning of the 1950s. The resulting cadastral systems were full of errors. In the territories placed under Polish administration following the Potsdam Agreement, much German-owned land was expropriated. Also, the lands of the Roman Catholic Church and the Polish aristocracy were expropriated to a large extent. Before World War II, several families in Poland owned more than 100,000 ha.

World War II created special difficulties for that area of Germany taken over by Czechoslovakia in 1945 known as Sudetenland. About 3 million Germans were expelled with the result that the government of Czechoslovakia wished to establish new settlements with their citizens as soon as possible. The transfer of such a large amount of real estate to new owners was an enormous operation and could not be managed by normal procedures. For that reason the documents were based on a simplified descriptive procedure to enable a fast transfer of ownership to the new owners. In many cases, the parcels belonging to one property were only determined by the house number. The parcels were not surveyed and therefore not correctly determined. The 
transfer of ownership was only roughly determined on the reallocation plans in a graphical manner. After the 1948 collectivisation was carried out by the communist regime all monuments and evidence of individual parcels were destroyed. As a result of all these developments the identification of the majority of the parcels today is only based on very poor graphical reallocation plans with most of the boundaries not surveyed. Moreover, a lot of reallocation plans were severely damaged or even destroyed. Sometimes there exist only draft plans. Land consolidation was also attempted to reach a better arrangement of parcels; however, the reallocated parcels have no relation to the old cadastral parcels and maps. Therefore, the setting out of cadastral boundaries today in Sudentenland is almost impossible.

\section{The introduction of centrally planned economies by Communist authorities}

The example of the Czechoslovakia highlights the impact on land administration caused by the introduction of centrally planned or command economies in Central Europe.

In most of the CEC prior to the communist era, the cadastral system consisted of two parts: the Land Register, where titles to land were recorded in registers, and the Cadastral Offices, where a systematic inventory of land parcels was kept on cadastral maps.

In Czechoslovakia close co-operation of Cadastral Offices with the Land Register was dramatically broken in 1948 when the Communist Party assumed administrative power. (Note this paper uses the FIG definition of cadastre (1995) which incorporates both the Cadastral Offices and Land Registers within "the cadastre".) In 1951, the obligatory ownership entry into the Land Register was cancelled by law. That meant the end of a long lasting principle of recording land ownership and cadastral changes. Nevertheless, until 1958, the updating of cadastral maps and the associated Land Registers continued. At the beginning of 1954, the cadastral documents associated with ownership records were not systematically up-dated and therefore they gradually became obsolete. Fortunately they were not destroyed. Owners of agricultural land were forced to enter co-operatives together with their immovable assets. Their ownership was maintained and registered, but the free use of the fields was strictly limited. Mainly for statistical purposes a uniform land inventory was introduced in 1956.

\section{The fall of the communist regime and the introduction of a free market economy}

The collapse of the command economies had an equally dramatic affect on land administration in the $\mathrm{CEC}$ as can be seen in the examples below. The resulting changes are the focus of current land administration reforms in these countries.

A crucial moment in Poland with regard to property was the amendment of Article 7 of the Polish Constitution in 1989. It states that 'the Republic of Poland protects ownership and the right of inheritance, and guarantees protection of personal property. Expropriation is only allowed for public purposes and after fair compensation'. The protection of ownership in the Constitution has resulted in important changes in the perception of private property in Poland. A land and property market is developing, resulting in a substantial increase in demand for reliable information concerning the owner and the determination of the legal boundaries of land.

The 'Velvet Revolution' in Czechoslovakia in 1989 resulted in the establishment of a market economy as a consequence of privatisation of state property and restitution of private land rights. This meant the registration of ownership and properties with their boundaries became necessary. As a result appropriate cadastral laws were enacted in 1992.

At the same time this raised the problem resulting from the expulsion of the 'Sudeten' Germans discussed above. After 1989 the problem of the expulsion was the subject of many discussions in the country. It was expected that many 'Sudeten' Germans would want to come back and claim their original properties. Therefore, the government decided that restitution of property could only be based on the situation after 1948 (after the expulsion). The problem was further complicated by another transmigration which took place in Czechoslovakia between Hungarian and Slovak citizens at the same time. On January 1, 1993 Czechoslovakia was split into the Czech Republic and the Slovak Republic. From this date these countries then developed their own land administration strategies.

Following the political changes of 1989-1990, the new Hungarian government declared that the next main step of development was to change the land ownership structure. This major step was started by the enactment of the Compensation Acts. The enactment of the Compensation Acts can be considered as the third and the largest land reform in Hungary. The first Compensation Act came into force in 1991. It was intended to compensate those persons whose private properties were expropriated after 1939 as a consequence of legal regulations of that time by issuing "Gold Crowns" which could be traded for land. The additional Compensation Acts expanded the circle of persons entitled to compensation.

\section{Summary}

As can be seen from the above examples of the impact of war and political changes on the CEC over the last 
century, these historical developments in the region continue to have a dramatic impact on any proposed land administration reforms. While the central theme for today's land administration reforms are the privatisation of state lands and co-operatives, and restitution of lands expropriated under the communist regimes, founded on issues of justice, there are many complications. Due to the world wars, there have been major changes in national boundaries with the result that countries like Poland have legacies of different historical cadastral systems, making the establishment of a national approach very difficult. At the same time, the issue of restitution of rights based on issues of justice is not a simple matter since many of the countries in the region have expelled minority groups over the years for one reason or the other. These issues could be resurrected when the CEC join the EU. The transmigration of minority groups has also created major problems since the resulting settlement by other groups has often been done quickly with poor documentation. At a more practical level, each CEC has used slightly different approaches to restitute land rights making any EU strategies even more difficult. Needless to say any land administration reforms in the CEC must be aware of the historical events of the past century and the dramatic impact they have had on the relationship of humankind to land in the region.

\section{Reconstruction of property rights}

The cadastral systems in Central Europe have a long history. Two systems are dominant in this region. The first is the 'Grundbuch' system that was introduced in Prussia in 1871 . The principle of this system was that no land transaction would be valid unless a proper conveyance was registered. The entry in the appropriate register, the 'Grundbuch', was to be sole evidence of title to land. The 'Grundbuch' system has many similarities with the cadastral service that was established in the regions covered by the Austro-Hungarian Monarchy in 1792. This system is known as the 'Maria Theresia Cadastre'. It is still the basis of the land registration in eight countries in Central Europe, including the Czech Republic, Hungary and the Slovak Republic.

The so-called 'Danube' countries have regular conferences dealing with the exchange of information on the progress of the modernisation of the Maria Theresia Cadastre.

Immediately after the collapse of the communist regimes in Central Europe the countries started the reconstruction of property rights on the basis of their historic cadastral systems. The reconstruction of property rights is in fact the re-establishment of the historic cadastral systems. This reconstruction is on-going and interwoven in the process of privatisation of land and property. The process is without doubt the major cadastral activity in the post-communist period in Central Europe.

In order to understand the privatisation process, it is useful to consider the two types of collectivisation used during the communist period and to have some insight into the difficulties in restituting lands. The first type of collectivisation is the full expropriation of land and property, which was consolidated into state farms and other state organisations. In the second type, land and property were brought into co-operatives. In a cooperative, an owner's land was not expropriated, but his/her property became part of a large land use complex. In a co-operative, the boundaries and land parcels were erased and disappeared in the terrain.

\section{State farms}

In Central Europe, there are different processes of privatisation of land and property. Farm lands of private owners were not expropriated in several countries. In Poland farm land stayed in the hand of private farmers. Here, the fight for freedom by small farmers over one century was also a fight to have private properties. The communist authorities never dared to collectivise these farm lands. In Poland, the situation was further complicated as a result of the Potsdam Agreements after World War II, where much Germanowned land was expropriated. Also, the Roman Catholic church and the Polish aristocracy had their lands expropriated to a large extent. These lands were brought into about 1700 state farms.

For the transformation to a free market in Poland, the privatisation of state-owned property was necessary. At the beginning of the reforms, in 1989, the government owned about $80 \%$ of all industry. Only small and obsolete companies were in the hands of private persons. The situation in agricultural activities was completely different. Here, the governmental sector owned only about $19 \%$.

In order to transform ownership to private persons in Polish rural areas, the Agricultural Property Agency of the State Treasury (APA) was established in 1991. The Agency is a trust organisation, authorised by the State Treasury to transfer ownership and other real property rights regarding state property in rural areas. The agency was obliged to take over all the property of the liquidated state-owned farms and other agricultural property of the State Treasury, as well as land and property from the National Land Fund.

Realising that private agriculture is and will be the dominant mode of production in Poland, it was assumed that the State Treasury Stock of Agricultural Property would result in increasing existing family farms as well as establishing new ones. In total, since the beginning of the Agency's operation until May 1, 1998, 
$46,200 \mathrm{~km}^{2}$ were transferred to the APA stock. From this area $37,500 \mathrm{~km}^{2}$ came from about 1700 liquidated State Farms; $5850 \mathrm{~km}^{2}$ was taken over from the State Land Fund; and $1750 \mathrm{~km}^{2}$ from other state entities. The APA stock covers about $15 \%$ of the total rural area of Poland.

Also, in other countries the Land Fund owns a large part of the rural area. In the Czech Republic and the Slovak Republic the Land Funds own about 10\%.

In most CEC where the original owners had lost their land because of the violation of effective legislative provisions or where land was taken over without legal grounds or by political persecution, they can claim their properties. In Poland, however, the government created a major political issue among claimants by boldly announcing in May 1991 its intention not to award any claims where expropriations were in accordance with the law at that time. This nullified almost all present claims as most nationalisation was permitted under the Stalinist expropriation laws.

Even in countries where claims were restituted, the Land Funds kept a reasonable amount of land. An important type of privatisation is also to sell or lease these former state lands to private owners. However, there are many restrictions on such sales, such as the requirement of the nationality of the purchaser. The offering of so much land for sale also had a devastating effect on the land market. Today, these Land Funds still own a substantial amount of land which has not been restituted, sold or leased.

\section{Co-operatives}

In Central Europe there are two processes for the restitution of property rights in co-operatives:

- Restitution: This is the restitution of land and property to the original owners or their heirs. Restitution is very difficult. Sometimes the original land parcels have disappeared under roads or buildings, and sometimes the original owners cannot be found. For example, in Warsaw, $60 \%$ of the original owners could not be traced. Restitution is the main type of privatisation in the Czech Republic and the Slovak Republic.

- Compensation: In this type of privatisation, the former owners get compensation for their land and property. Most of the time such a compensation consists of land parcels and not money. A good example is the Compensation Programme in Hungary.

Following is a brief review of progress in reconstructing property rights in the former co-operatives in the Czech and Slovak Republics, which show typical problems. Before 1948, there were about 12 million land parcels in both the Czech Republic and the Slovak
Republic. From these numbers, about $20 \%$ were situated in built-up areas and $80 \%$ in rural areas. In the built-up areas, about $90 \%$ have now been registered in the cadastre with owners having received ownership certificates.

In the rural areas, about $20 \%$ of the land parcels could be reconstructed; however, to date, only a very small part have had an ownership certificate issued or had their location determined. The majority of the reconstructed parcels have an ownership certificate without an exact location.

The majority of farming in this area is still in the hands of co-operatives with the co-operatives having been divided into smaller units. Not only co-operatives, but also public limited companies and other companies are active. The size of private farms lies between 20 and 50 ha. Only $10 \%$ of farming is done by private land owners. For many reasons, such as poor land, no buildings or poor buildings and poor equipment, private farmers have to struggle to survive.

As can be seen, the major problem is the privatisation of land parcels in rural areas. The reconstruction of the remaining part of the former cadastral parcels in the Czech and Slovak Republics is known as the problem of the 'missing' parcels (about 7 million in the Slovak Republic and about 8 million parcels in the Czech Republic). The problem is not only the extreme fragmentation of parcels into narrow strips in former times (Fig. 3) compared to the parcel structure within a co-operative during the communist era (Fig. 4), but also the excessive number of co-owners of the parcels due to the nature of the inheritance laws of the former AustroHungarian Empire. One example is given of parcel number 4165 of the cadastral unit Liptovska Ondrasova (PHARE, 1998). This is a land parcel of $170 \mathrm{~m}^{2}$ with 120

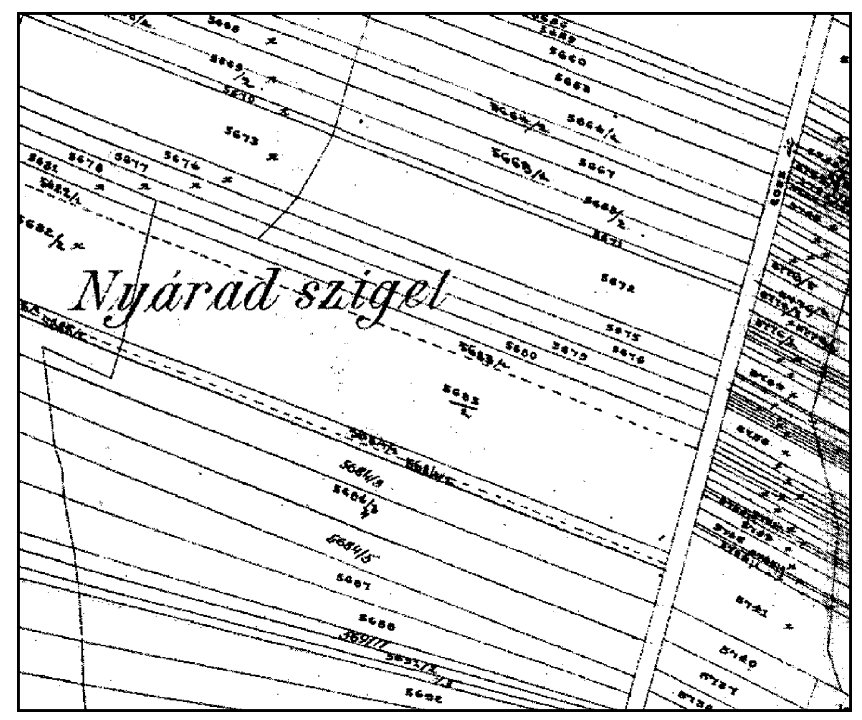

Fig. 3. The rural Slovak Republic cadastral framework showing the reconstruction of property rights (and parcel fragmentation). 


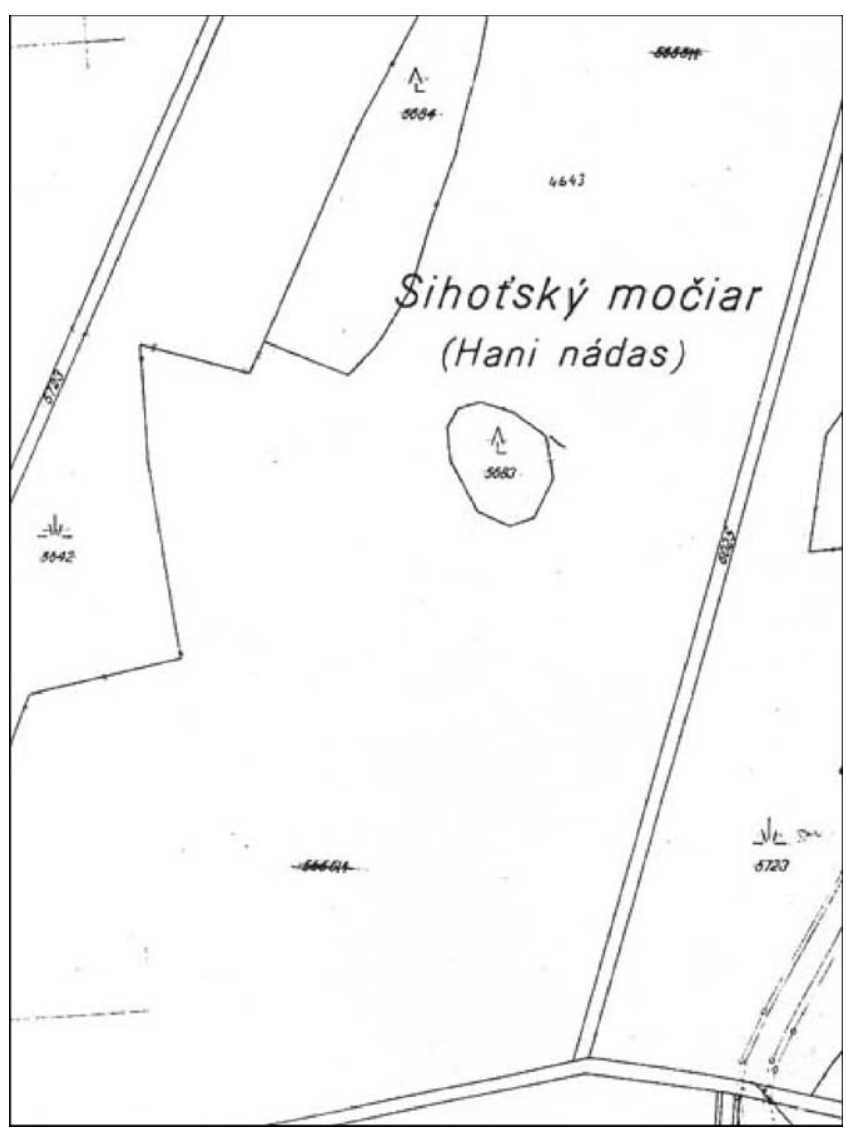

Fig. 4. The rural Slovak Republic cadastral framework of the same land as Fig. 3 as a co-operative during the communist era.

co-owners, where co-owner number 24 has a share of $2827 / 33,592,320$ which equals $0.07 \mathrm{~m}^{2}$, which is about the size of a sheet of A4 paper. This situation is common.

As mentioned, Hungary is a good example of the use of compensation. In Hungary, the Compensation Act I came into force in 1991. On the basis of this act, persons who suffered from the communist regulations effected after June 8, 1949 were compensated. Compensation Act II came into force in 1992. On the basis of this act, those persons who suffered from the regulations effected between May 1, 1938 and June 8, 1949 were also compensated. The unit of compensation (a document or certificate) is called the "Gold Crown". The "Gold Crown" value is the so-called cadastral net income of a plot. It was the basis of land property tax from 1875 . At auction, participants could make a bid for the appropriate value of one Gold Crown.

After the fall of the communist regime, a major focus on land distribution has occurred in Hungary as a result of these Compensation Acts from 1991 to 1992. The number of persons entitled for compensation exceeded $1,040,000$. It was necessary to nominate the part ownership of about 1,600,000 co-operative members as well as the land ownership of 500,000 employees of agricultural co-operatives and state farms who also received pieces of land on the basis of the Compensation Acts.

Three quarters of the area of Hungary are touched by the Compensation Acts in one way or another. The auctions for specific areas are prepared by compensation committees. In some areas, agreements with the former owners and the local government still have to be made. An obligation of the Cadastral Land Offices is that they have to set out these new parcels in the field. This is still done for about $40-50 \%$ of the compensation parcels. The division of the areas during compensation was done in a very simple way which led to strange shapes for the new parcels. In most cases, the boundaries were set out parallel to each other with all the parcels having about the same length. Many owners of new vouchers got extremely small parcels with some examples of parcels of $7 \mathrm{~cm} \times 600 \mathrm{~m}$ !

\section{The evolution of land administration}

A fundamental principle of land administration systems is that they continually evolve in response to the changing humankind to land relationship. These changes are driven or strongly influenced by global drivers such as sustainable development, urbanisation, economic reform, globalisation and technology (Ting and Williamson, 1999, 2001; Ting et al., 1999; Williamson and Ting, 2001).

Land administration trends have followed a course mapped by dynamic changes in societies and their increasingly complex attitudes to land as personal security, wealth, as an expendable commodity, as a scarce community resource, in support of environmental survival and sustainable development (Ting and Williamson, 1999). This continual change can be seen in the context of "western" land tenure systems in Fig. 5.

A review of the dynamic humankind-land relationship (Ting and Williamson, 1999) shows that in a western context, it may be classified into four broad phases:

- Human settlement during the agricultural revolution through the feudal system, which tied human beings to land in a physical way. Land was the primary symbol and source of wealth. In this phase, the cadastral system's role was to publicly record ownership as well as for fiscal purposes.

- The Industrial Revolution began a process of breaking that strong physical tie to land by turning land into more of a commodity, albeit the most valuable commodity and primary source of capital. In many western countries, the mobility of people and the rise of capital and commodification of land brought by 


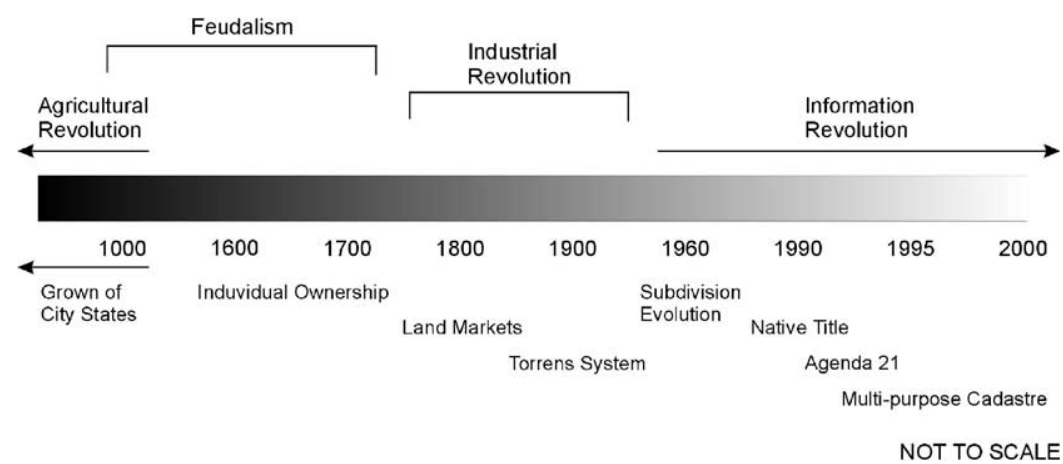

Fig. 5. A western view of the changing humankind to land relationship (Ting and Williamson, 1999).

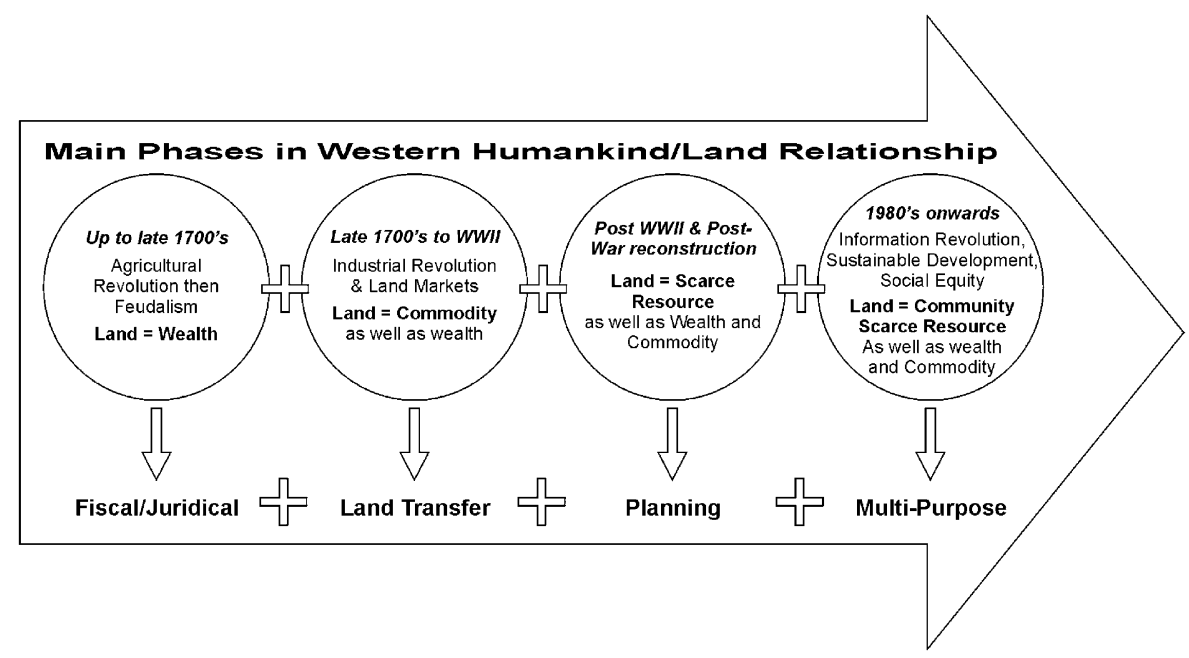

Fig. 6. Main phases in the western humankind to land relationship (Ting and Williamson, 1999).

the Industrial Revolution, gave birth to major legal and institutional changes. This environment gave birth to land markets and so cadastre took on another focus - a tool to support land transfer and land markets. The Torrens system of land registration developed in Australia (which has spread to many countries worldwide) is a good example of the institutional and legal responses to the burgeoning of land markets in the 19th Century.

- The post-World War II reconstruction and the population boom saw an awareness of land as a scarce resource that was not sufficient for the needs of a growing world population which was becoming more mobile. With this came an interest in planning, particularly urban and regional planning. Planning in turn created another application for the cadastre.

- The 1980s have seen a different twist in the concern for the scarcity of land. The focus has turned to wider issues of environmental degradation and sustainable development, as well as social equity. All of these issues have the probable effect of tempering shortterm economic imperatives. Planning issues have widened to include more community interests and deepened to address more detailed issues of land use. This has created a growing need for more complex information about land and land use. The impact of these has been manifested in the desire for multipurpose cadastres.

The land administration response to these changing phases is shown diagrammatically in Fig. 6.

The evolution of land administration systems and particularly their cadastral components can be seen in such documents as the International Federation of Surveyors (FIG) Statement on the Cadastre (FIG, 1995), the UN-FIG Bogor Declaration on Cadastral Reform (FIG, 1996), the UNECE Land Administration Guidelines (UNECE, 1996) and the UN-FIG Bathurst Declaration on Sustainable Development for Land Administration (FIG, 1999; Williamson et al., 2000). A broad view of evolving land policies, particularly from a World Bank perspective can be seen in Deininger and Binswanger (1999). 
The Bathurst Declaration concluded that "most land administration systems today are not adequate to cope with the increasingly complex range of rights, restrictions and responsibilities in relation to land, which are influenced by such factors as water, indigenous land use, noise and pollution" and "governmental information systems will have to continue their present trend to become increasingly open and public... and governments have an important role as umpire, moderator and purveyor". In short, land information and land administration systems need to be re-engineered and to evolve to face the increasing complexity of the humankind-land relationship. Since many existing land administration systems are still based on a relatively narrow land administration paradigm centred on land registration and cadastral surveying and mapping, a new paradigm is required. Importantly, these trends are in sympathy with the objectives of the Acquis Cотmunautaire.

This "western view" of the land administration response has not been followed by the CEC. Prior to the introduction of the communist regimes, the CEC were at various stages of the evolutionary model. In the first half of the 20th Century, some of the countries (especially in rural area) were still feudal while some had been influenced by the Industrial Revolution and were supporting rudimentary land markets. Fiscal cadastres had been introduced in most countries. The cadastral landscape of the CEC up to World War II exhibited private properties for the most part in urban areas but in rural areas there was increasing complexity with enormous fragmentation into small, often unusable strips of agricultural land (Figs. 2 and 3). The complexity was further compounded by multiple ownership of land, which made land transfer or the mortgaging of land very difficult, if not impossible.

As highlighted in this paper, the major influence in recent times was the introduction of command economies with little or no private ownership of land. Also, as explained in this paper, after the fall of communism, for the most part the CEC wanted to return to the cadastral landscape prior to the World War II and the communist era, as the first step in addressing the injustices of the communist era.

However, in the intervening period between the 1940s and the early 1990s, land administration systems had evolved significantly, particularly in Western Europe. Issues of fragmentation and multiple ownership were being addressed by land consolidation to a large extent; planning laws had been introduced and there was a much greater awareness on the role of land in contributing to environmental and social objectives. The legal and institutional infrastructures had evolved to the stage that they supported sophisticated land markets. In simple terms, the land market paradigm of the pre-World War II era which was based on a simple economic objective, had been replaced in Western European countries by a much more complex land administration infrastructure where the economic driver is increasingly being tempered by environmental and social priorities. These new priorities are reflected in the Acquis Communautaire of the EU.

Therefore, the restitution of property rights in the CEC today is not simply a matter of returning to the cadastral landscape of the pre-communist era, but of instituting the land administration infrastructures demanded by the Acquis Communautaire as a pre-requisite to accession to the EU. The following section explores key principles of the Acquis Communautaire in the context of evolving land administration infrastructures.

\section{Criteria for accession}

Having reviewed changes in land administration in the CEC over the last century and examined trends and the evolution of land administration systems, five key criteria for the accession of candidate-members for the EU are reviewed in the context of land policies and land administration. They are the protection of human rights, the adoption of the EU Common Agricultural Policy (CAP), institution building, environmental sustainability and the establishment of a free-market economy. It is recognised that these are not only the criteria which are supported by an effective land administration infrastructure, but the authors believe that they are the main areas.

\section{The protection of human rights}

Every European citizen remembers the tragic fate of minorities during World War II. It resulted in an almost complete extermination of the Jewish population. Other minorities that suffered were, for example, gypsies and homosexuals. Unfortunately, after World War II the mistreatment of minorities continued, such as the expulsion of the Sudeten Germans and Austrians from their homeland. One of the main reasons for the establishment of the EU is that these tragedies should never happen again.

For this reason, the protection of Human Rights is one of the most important topics of AGENDA 2000 'For a stronger and wider Europe'. Unfortunately, the creation of new states in Central Europe, the shift of boundaries and large transmigrations during the last century, and especially as a result of World War II, have created new minorities. In many CEC, this has created both citizens and "non-citizens".

The position of non-citizens can best be described with the situation in Latvia. In this country, the minorities count for nearly $44 \%$ of the population. They include 30\% Russians, 4\% Belarussians and 3\% 
Ukrainians. Latvians are a minority in seven of the country's eight largest towns. The process of naturalisation has not granted Latvian nationality to many people in the minorities. The issue of special passports to them gives them more rights, for instance, the freedom of movement, however, "non-citizens" continue to be affected by various types of discrimination. They are barred from certain occupations, they have no rights to vote and they cannot directly acquire ownership of land.

The position of minorities of citizens is also highlighted by the situation in Hungary. After World War I, the Austrian-Hungarian Empire was divided into different states. Hungary became smaller than the area occupied by the Hungarian population. This created large "Hungarian" minorities in countries like Slovakia, Romania and Serbia. In some cadastral areas in Slovakia, there are up to $90 \%$ of land owners of Hungarian origin. The protection of their land and real estate is considered as one of their basic rights.

The EU respects and promotes the universal principals as laid down in the 'Universal Declaration on Human Rights'. To strengthen the protection of fundamental rights, in the light of changes in society, social progress and scientific and technological developments, those rights are made more visible in an EU charter. The draft of this charter made in September 2000 contains 54 articles, where article 17 deals with the rights to property:

Everyone has the right to own, use, dispose of and bequeath his or her lawfully acquired possessions. No one may be deprived of his or her possessions, except in the public interest and in the cases and under the conditions provided for by law, subject to fair compensation being paid in good time for their loss. The use of property may be regulated by law insofar as is necessary for the general interest.

An important aspect of the protection of human rights is the protection of private real property by the government. In the countries in Central Europe, about $70 \%$ of the assets of people are in land and real estate. It is a basic tenet that a democratic government and a good cadastral system go hand in hand. Civilised life is based to a large degree on the fact that people know who owns what. Without an effective land administration infrastructure, it is very difficult to restitute land rights, provide compensation for properties which were confiscated during the communist era.

There are many examples of land reform all over the world that have failed because of the lack of privatisation of land and property. As stated by De Soto (1989, 1999), privatisation processes in Latin America in 1824, $1840,1870,1910,1930$ and later on in the 1980s and in 1990 failed with this reason being a major contributing factor. Every time there was a return to militarism and dictatorship accompanied by the lack of a competitive economy, there was failure. De Soto emphasises that civilised life is based to a large degree on people knowing who owns what. Human rights are intimately connected with issues of private property. An up-to-date cadastral system (albeit in an appropriate form) - maintained by the government - is a pre-requisite for the protection of real property.

\section{Common Agricultural Policy of the EU}

1999 was a landmark year for the Common Agricultural Policy CAP. As it evolved over the last 40 years, the EU's agricultural policy has undergone considerable change to keep pace with developments both inside and outside the EU. The AGENDA 2000 package, agreed in March 1999, represents the most radical and wideranging reform in the history of the CAP (EU, 1999).

In formulating these policy proposals, the Commission identified several key priorities:

- to ensure the competitiveness of the EU's agricultural sector, both on the Community market and on growing export markets;

- to promote ways of farming that contribute to the maintenance and enhancement of rural environment and landscapes; and

- to contribute to sustaining the livelihood of farmers while promoting the economic development of the wider rural economy.

The proposals were based on expert analyses and forecasts of market developments in the EU and worldwide. They were widely discussed both within the EU institutions, as well as with representatives of socioprofessional groups and other interested parties. In short, the new policy seeks to support the maintenance of a specific model of agriculture, which is a key part of Europe's heritage, and one that recognises the multifunctional nature of European agriculture and the wide range of benefits it produces (EU, 2000).

The main challenges for CAP in the future fall into three broad categories. Internally, the EU will continue its efforts to improve the environmental sustainability of agricultural production in the long term and to integrate policy in a coherent overall strategy for their rural areas, ensuring their social and economic viability. In addition, it will seek to reduce the complexity of CAP management and to simplify it where possible.

On the external front, the challenge lies in continuing to adapt EU agriculture to an increasingly competitive international context characterised by further moves towards trade liberalisation.

In pursuing this strategy, the Union will also be in a better position to face its third big challenge; that is, enlargement of the EU to the East. This will include the countries of Central and Eastern Europe, which could 
potentially double its farm population and increase its agricultural area by more than $40 \%$.

In order to execute the CAP, the EU has established and maintains a tool called Integrated Administration and Control Systems (IACS) which are obligatory for all member states.

The starting point for the EU CAP is that agriculture should adapt to changing markets developments, policy and rules of trade. Furthermore, the rural regions must fulfil two functions with respect to environmental protection and recreation. An important role of the CAP is reserved for instruments for sustainable development of rural areas. Regulations 3508/92 and 3887/92 of the EU contain detailed requirements for the content and use of the IACS. The integrated system must consist of the following components:

- an alphanumeric identification system for rural land parcels;

- an automated database;

- an alphanumeric system for the identification and registration of animals;

- rules for requests for subsidies; and

- an integrated control system.

The parcel identification system must be established on the basis of a cadastral system, cartographic maps or aerial photographs.

In 1996, interesting research was carried out with respect to the use of GIS technology in IACS. From a pilot study of one million land parcels, it was concluded that while GIS is not explicitly prescribed, that nine member states are using this technique in some way to achieve the objectives of IACS.

At this moment, half of the EU budget is spent on farm subsidies, whereas the support of structurally weak regions amounts for one-third. The situation in Central Europe with uneconomic small farms with a very unfavourable scattered cadastral parcellation makes the accession to the EU a difficult task from an agricultural perspective. The West-European farmers will not be enthusiastic about the fact that a large part of the shrinking EU subsidies will go to Central Europe.

Since the regulations for subsidies of the EU (Structural Fund and Cohesion Fund, and SAPARD Fund [EU, 2001b]) are based on IACS, CEC are also developing such systems. The obvious relationship between the development of IACS in rural areas in CEC and the modernisation of the cadastral systems, especially in rural areas, is obvious with each benefiting and supporting the other.

\section{Institution building}

Since 1990, financial support from the EU for CEC was streamlined via the PHARE Programme. In the beginning of its activities, PHARE supported the development of the free market economy, whereas today PHARE's activities concentrate on the support for the accession of candidate CEC to the EU. Thirty percent of the budget of PHARE is for institution building. The strengthening of the institutional and administrative capacity of the candidate countries is a key requirement for enlargement of the EU. This capacity is necessary in order to be able to implement and to enforce the Acquis Communautaire. In all the CEC, PHARE is supporting the process of institution building in at least four key sectors: finance, justice and home affairs, agriculture and the environment.

With respect to the land registration sector, the CEC Ministries of Justice and Home Affairs play a crucial role; Justice in case of land registration and Home Affairs in case of the cadastre. However, there are different approaches in different CEC where the cadastre is fully under the jurisdiction of Agriculture (Hungary) and countries where the responsibility for the land registration sector lies with an independent organisation directly under supervision of the Office of the Prime Minister (Czech Republic). In general, land administration is an important part of the public administration within one or more ministries, which are supported by the institution building programme within the framework of PHARE.

In the CEC, government is concentrated on a district level, where land administration is an integrated part of the government as a whole. In Poland, the Czech Republic, the Slovak Republic and Hungary, there are, in total, about 700 Cadastral Offices. The institutional reform of these regional and local authorities is strongly influenced by two technical developments:

- Database technology: The question is if cadastral databases should be kept in the local Cadastral Offices and local courts or if this should be more concentrated on higher level;

- Improvement of telecommunication by mobile phones and Internet facilities: With these modern possibilities the place where the cadastral information is stored and kept is now less relevant.

The emphasis on institution building in support of sustainable land administration systems is also mirrored in the land titling, cadastral and land administration projects supported by the World Bank over the last decade (Deininger and Binswanger, 1999; Williamson, 2000).

Considerable efforts have been made to train civil servants and judges and to reinforce the independence, professionalism and effectiveness of public administration and the civil service. Due to the lack of experience and capacity in CEC in establishing appropriate land administration systems, an equal commitment of institution building to land administration will be critical 
if the CEC are to develop their land systems to meet the objectives of the Acquis Communautaire.

Needless to say, the building of appropriate land administration institutions is essential to the establishment of an efficient and effective land market, which in turn is essential to the creation of a free market in the CEC, which in turn is one of the key principles of the Acquis Communautaire which CEC have to meet for accession to the EU.

\section{Environmental sustainability}

A key requirement for accession to the $\mathrm{EU}$ is the adoption of environmental sustainability and effective natural resource management, including forest management. This requires a range of laws, regulations and institutions. Just as important is the establishment of an infrastructure which allows environmental standards and policies to be implemented and monitored.

AGENDA 2000 established an Instrument for Structural Policies for Pre-Accession (ISAP) (EU, 2001b) which together with PHARE provides some EURO 1 billion (2000-2006) towards aligning applicant countries on Community infrastructure standards (by analogy with the Cohesion Fund), with a major focus on environmental sustainability. Also, "Energy, Environment and Sustainability" is one of the four thematic research programmes of the EU Fifth RTD Framework Programme (1998-2002) (EU, 2001c). Sustainable development is also promoted in candidate countries by the European Consultative Forum (EU, 1998). Finally the Regular Reports from the EU on the progress of accession of CEC considers the "environment" as one of the key aspects in meeting the objectives of the Acquis Communautaire.

This is supported by the World Bank (Wiebe and Meinzen-Dick, 1998) where "...the recognition that sustainable development, and the efficient and equitable use of resources on which it is based, depends critically on the ways in which property rights are defined and distributed...".

A key component in a land administration infrastructure is the documentation of all public as well as private rights in a country. This means that all state lands, forests, parks and reserves should be recorded in the cadastre. Just as important is the establishment of a cadastre showing important private rights, restrictions and responsibilities. This cadastre then provides an infrastructure to facilitate land use planning in both urban and rural areas.

Increasingly, the cadastre is seen as the key component within a national spatial data infrastructure (Williamson et al., 2000; Williamson, 2000). Within a spatial data infrastructure, cadastral data can be combined with topographic data, remotely sensed data and specific natural resource data sets to provide an essential infrastructure for environmental decision making as well as having a wide range of uses in such areas as transportation planning.

As stated previously, if a state does not know who owns what properties, it is impossible to administer and manage land in the broadest sense. It is only through the establishment of effective land administration systems (and more importantly the provision of an effective land administration infrastructure) that environmental sustainability objectives can be efficiently met.

\section{Establishment of an effective free market}

A requirement for accession is that the candidate countries must have a functioning free market economy, as well as the capacity to cope with competitive pressures and market forces within the EU.

However, under the communist regimes there existed a centrally planned economy with the following characteristics (quoted from Niklasz et al., 1996):

- A legal framework, which executes administrative procedures through a regulatory framework which has full support of the legal process. The result of this is that low level activities of the administrative system are defined by law, placing severe restrictions on the activities, and also on the methods that can be used to support these statutory obligations. Consequently, even minor changes in procedures require an amendment to the relevant law;

- A reliance on centralised budgeting and planning, which reduces the opportunity for local innovation and places the emphasis of responsibility upon compliance with ministerial level directives, rather than encouraging administrative officers to assume local responsibility, where relevant;

- A lack of knowledge of the true costs of operations undertaken by the administrative sector, which can be translated, at worst, into a perpetuation of activities that may be unnecessary, or at best activities are undertaken without due regard for the costs/benefits from those activities, and an unawareness of the financial implications of decisions;

- A vertically oriented command structure, with few direct lines of communication for technical staff, other than through the administrative management process. This creates bureaucratic difficulties in the execution of the day to day activities. The horizontal communication lines are weak in this system;

- An abrogation of the decision making process, whereby decisions are undertaken at a centralised senior level, with the consequent risk that the decision makers may appear remote from the real problems;

- A philosophy which depends upon state budget allocation for the execution of activities, rather than seeking an understanding of user needs (public 


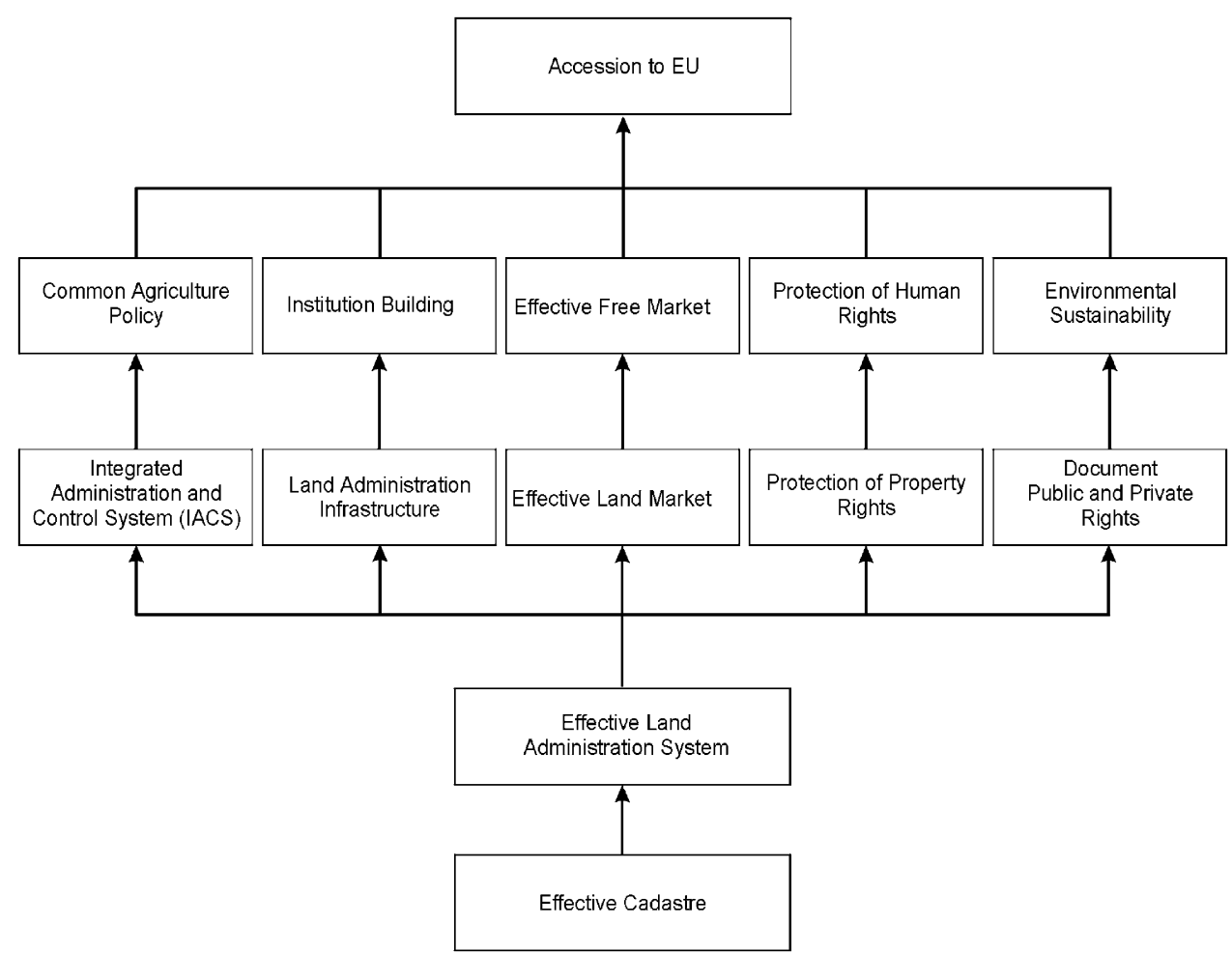

Fig. 7. The role of land administration in the accession of CEC to the EU.

and private sector), and then seeking means of cost recovery;

- The maintenance of large sectors of the economy under direct government control, which reduces the involvement of the private sector and small and medium sized enterprises (SMEs) in particular. This reinforces the status quo.

A free market requires the establishment of a free land market and the determination of private property rights (UDMS, 2000; World Bank, 1999). Without an effective land administration infrastructure under-pinning the land market, it is very difficult if not impossible to buy, sell, mortgage or lease rights in land. The necessity of having clear title to land in a country is also very important if foreign investors are to be attracted.

Also, without an appropriate land administration infrastructure, it is difficult if not impossible, to undertake land consolidation programmes which can address the creation of small scattered land parcels having multiple owners, during the privatisation process in rural areas. In many cases, unless the issues of fragmentation and multiple ownership can be addressed, it is almost impossible to establish an effective land market.

A key component of an effective land market is the establishment of a system of property tax which allow fair and equitable resumption of land by the state, ensure that fair and equitable land transfer taxes are raised and permit local government to apply local land taxes in a fair and equitable manner. Again without an appropriate land administration infrastructure, the establishment of a equitable property taxation system cannot be established.

\section{A land administration framework to support accession of $C E C$ to the $E U$}

This paper has introduced the complex land issues in CEC and described how resolving these issues by establishing appropriate land administration systems is central to achieving the objectives of the Acquis Communautaire. This in turn is central to the accession of the CEC to the EU. Fig. 7 is a generic framework which describes how land administration contributes to most of the key EU policies in the Acquis Cотmunautaire. The paper has shown that the relationship between these EU policies and land administration are supported by international trends in the development of land administration systems.

The framework starts with the premise that the establishment of an appropriate, effective and efficient land administration system is a key component in the strategies to achieve the protection of human rights, a Common Agriculture Policy and an effective free market. The framework also recognises the essential role that institution building plays in establishing a land administration system. Through the framework, the 
establishment of an appropriate land administration is linked to the accession of CEC to the EU.

More specifically, the framework recognises that an appropriate land administration system specifically supports the IACS which in turn supports the CAP. Related to the CAP is the need for environmental sustainability which is under-pinned by the documentation of all public as well as private rights in land. An effective land administration system also supports the protection of property rights which in turn supports the protection of human rights. Also, effective land markets support an effective free market. Lastly, an effective land administration system will support a land administration infrastructure which in turn requires a major commitment to institution building.

\section{Land administration challenges}

CEC will face many challenges over the next decade in establishing land administration systems which will effectively address the objectives of the Acquis Communautaire and therefore support their accession to the EU. While many of these challenges have been identified by the authors in the paper and elsewhere (Bogaerts, 1999; Zevenbergen and Bogaerts, 2000), a more detailed review of the problems and challenges can be found in the proceedings of numerous meetings such as the recent 22nd Urban and Regional Data Management Symposium on Land Markets and Land Consolidation in Central Europe "Common Problems-Common Solutions", Delft University of Technology, the Netherlands, September 11-15, 2000 (UDMS, 2000) and the International Conference on the Development and Maintenance of Property Rights, The World Bank and the EU, UNECE, Federal Ministry of Justice and Federal Office of Metrology and Survey of the Republic of Austria, Vienna, May 26-29, 1999 (World Bank, 1999). Many of the challenges were identified by Bogaerts (1998) during his bi-annual strategic reviews of the cadastral systems of CEC (1992-98) under PHARE and have been summarised more extensively by Williamson (2001). A summary of the key challenges facing the CEC are listed below; however, it is acknowledged that a great deal of very good work has been done and is currently being done to establish the land administration systems in the CEC under very difficult circumstances. The challenges have been categorised from a policy to a technical perspective, however, no attempt has been made to prioritise the challenges since each CEC has specific requirements.

\section{(a) Relation to the $\mathbf{E U}$}

(i) Adoption of the Acquis: There is generally a poor understanding of the broader role of land administration and particularly cadastre in
CEC in meeting the objectives of the Acquis Communautaire and consequently the accession to the EU. This includes a poor understanding of how land markets operate and particularly mortgage systems, the role of long leases versus ownership and the role of land consolidation.

(ii) Developing a free land market: In most of the CEC, participation in the land market is restricted by the law to "nationals" of each respective country. This is against the Acquis Communautaire and it restricts foreign investment and to some extent human rights.

(iii) Colonisation: The many land administration pilot projects being undertaken in Central Europe by Western Europe are, in one sense, another form of colonisation. Each Western European country is trying to promote the benefits of its unique land administration system, sometimes to the detriment of the CEC. In general, Western European approaches are not applicable to the CEC. The Western European land administration systems have evolved over almost two centuries with very strong economies under-pinning them. It also appears that the penetration and protection of western technology is undermining local GIS capacity in CEC.

(iv) Spatial data infrastructure: There is a lack of understanding in CEC of the role and potential of the cadastre in a national spatial data infrastructure.

\section{(b) Strategy}

(i) Vision: In most CEC, there is a lack of a clearly defined national land administration vision and strategy with agreed targets. This results in an uncoordinated and piecemeal approach to developing cadastral systems.

(ii) Cadastral surveys: Most CEC are adopting precise cadastral surveys as part of the documentation of rights in land. This is expensive and slow. Precise cadastral surveys are not necessary as long as there is reasonable occupations or boundary monumentation. The key is that the cadastral system is map based, not based on individual isolated cadastral surveys. The adoption of boundaries which are "limited as to survey" offers many possibilities.

(iii) Multi-purpose: CEC have been encouraged to develop a comprehensive multi-purpose cadastre at one time, before a simple cadastre of basic property rights has been created. There is little recognition of the difficulties and time required to create a complex multi-purpose cadastre. A key to success is to start simple but 
incorporate sufficient components to allow the system to evolve and grow to serve multipurpose uses.

(iv) Land administration infrastructure: There is lack of appreciation that building a land administration infrastructure with an efficient cadastre at the core is a long-term strategy. There are no "short cuts". It is hard work which requires experience and dedication over a long period.

(v) Land administration evaluation framework: There is a need to establish an appropriate and accepted land administration evaluation framework for CEC.

(vi) User driven system: There is a need to develop a user driven system rather than a provider (government) driven system, based on a "service culture". This is very different from the culture during the communist era.

\section{(c) Transition problems}

(i) Inaccurate data: CEC are attempting to graft a private ownership system onto the existing cadastral systems (maps and registers) which were developed during communist times. In the existing systems, much of the geometric and descriptive data about land is inaccurate and does not correspond to the real world.

(ii) Privatisation: There is often a focus on the restitution of all pre-communist era rights. Privatisation of land has resulted in the formation of very small land parcels (see Figs. 2 and 3) with many co-owners and unfavourable shapes (Riddell and Rembold, 2000). These very small parcels are very inefficient for agriculture and cannot be sold easily. Moreover, it is very difficult to get a mortgage on these parcels. However, land owners will not undertake consolidation processes as in Western Europe due to the cost and lack of financial support. Low cost solutions must be found as suggested by Sonnenberg (2000). To date, the CEC have shown poor performance in privatisation, restitution and compensation of previously confiscated lands.

(iii) Informal transactions: The current restrictive, inaccurate and slow land administration system encourages illegal transactions.

(iv) Backlogs: The creation and operation of the new cadastral systems in the CEC are suffering from enormous backlogs. This results in cadastral systems being incomplete. The uncertainty in land titles is having a devastating effect on investments in land and real estate and severely limiting the operation of the fledgling land market.

\section{(d) Financing}

(i) Lack of finances: There is a severe lack of finances to establish effective land administration system in the CEC.

(ii) The role of Land Funds: About $10 \%$ of the national agricultural territory in each CEC is owned by Land Funds. These funds have the task to privatise the land by selling and/or leasing. Making so much land available distorts the market, because the financial possibilities of potential buyers or lessors are very restricted.

(iii) Title industry: The fledgling title industry which is evolving in CEC is expensive and slow.

(e) Legislation

(i) Legal infrastructure: The new legal infrastructure together with the existing legal framework is very restrictive.

(ii) Different owners of land and buildings: In CEC, there are often different owners of land and buildings which creates complexities in the land market.

\section{(f) Capacity}

(i) Training: There is a severe lack of capacity to develop appropriate land administration systems, particularly in the cadastral, legal and information technology areas. While there are many well-trained technical surveyors in the CEC, their training has not been on building modern land administration systems, and particularly modern cadastral systems, for obvious reasons. Also, the very multi-disciplinary nature of land administration (surveying, mapping, law, valuation, planning, administration, natural resource and environmental management, public policy) means that it has been very difficult to establish education and training programmes in the CEC to support the establishment of appropriate land administration systems.

(ii) Research: There is a lack of a land administration research focus or an EU supported Land Administration Research Centre to document all the experiences in Eastern and Central Europe, from PHARE and the many donor projects in the land related area. Much of the experience is lost.

\section{Conclusions}

$\mathrm{CEC}$ are facing major challenges as they endeavour to meet the requirements of the Acquis Communautaire as part of their accession to the EU. The Acquis lays down specific criteria including those concerned with establish- 
ing free markets, ensuring environmental sustainability, establishing appropriate government institutions, accepting the CAP and the protection of human rights. As explained in this paper, land issues are key components of these objectives. This paper argues that without an integrated land administration infrastructure in a CEC, it will be impossible to meet the requirements of the Acquis Communautaire which in turn will prejudice accession to the EU.

In order to understand the complexities of developing land administration infrastructures in CEC, the paper provides an historical overview of land issues in Central Europe over the past century and argues that without understanding these complexities it is difficult to develop effective land polices. Particular attention is given to current issues concerned with the reconstruction of rights. International trends in the evolution of land administration systems were reviewed and shown to be in sympathy with the objectives of the Acquis Coтmunautaire.

Since most, if not all, CEC do not have comprehensive visions or strategies to develop their land administration systems in the context of their accession to the EU, a framework has been developed to show the interdependence between the key components of the Acquis Communautaire and land administration, and consequently their accession to the EU. The paper concludes by highlighting a range of challenges which CEC face in developing appropriate land administration systems.

In summary, if CEC wish to meet the objectives of the Acquis Communautaire and join the EU, then much greater attention will have to be given to the establishment of appropriate land administration infrastructures, especially in rural areas (recognising the EU Cohesion Fund (EU, 2001a) promotes balanced urban and rural development throughout Europe).

\section{Acknowledgements}

The authors wish to acknowledge the support of the Technical University of Delft and the University of Melbourne which has permitted the preparation of this paper. They also wish to acknowledge Mr Axel Smits for preparing the diagrams. However, the views expressed in the paper are those of the authors and do not necessarily reflect the views of those persons who assisted in the preparation.

\section{References}

Baldwin, R., Bogaerts, T., Csaki, C., Dale, P., Zichy, A., 1999. Land markets in East and Central Europe. Report on ACE study for the European Union.

Bogaerts, T., 1997. A comparative overview of the evolution of land information systems in Central Europe. Computers, Environment and Urban Systems 21 (2), 109-131.
Bogaerts, T., 1998. Individual strategic review studies of the cadastral systems of Central European Countries (1992, 1994, 1996 and 1998 ) in the framework of PHARE. Department of Geodesy, Delft University of Technology, The Netherlands.

Bogaerts, T., 1999. Cadastral systems: critical success factors. Proceedings of the UDMS 99, 21st Urban Data Management Symposium, Venice, Italy, 21-23 April, pp. I.1.1-I.1.12.

Dale, P.F., 2000. The importance of land administration in the development of land markets: a global perspective. Proceedings of the UDMS 2000, Delft University of Technology, The Netherlands, 11-15 September, pp. 31-41.

Dale, P.F., Baldwin, R., 1999. Emerging land markets in Central and Eastern Europe. In: Csaki, C., Lerman, Z. (Eds.), Proceedings of the Second World Bank/FAO Workshop on Lessons for EU Accession, Warsaw, Poland, 27-29 June, World Bank Technical Paper No. 465, pp. 81-109.

De Soto, Hernando de, 1989. The Other Path: the Invisible Revolution in the Third World. Harper and Row, New York.

De Soto, Hernando de, 1999. The Mystery of Capital. Basic Books, New York.

Deininger, K., Binswanger, H., 1999. The evolution of the World Bank's land policy: principles, experience, and future challenges. The World Bank Research Observer 14 (2), 247-276.

EU, 1997. Agenda 2000, for a stronger and wider Europe. Commucation of the Commission, Strasbourg, 15 July, European Commission. http://europa.eu.int/comm/enlargement/agenda2000/ strong/1.htm, accessed 8 February 2001.

EU, 1998. European Consultative Council. Press release on sustainable development in Commission and candidate countries in Europe. http://www.europa.eu.int/comm/environment/press/bio98594.htm, accessed 8 February 2001.

EU, 1999. The Common Agricultural Policy-1999 review. European Commission-Directorate-General for Agriculture. http://europa.eu.int/comm/agriculture/publi/review99/full_en.pdf, accessed 8 February 2001.

EU, 2000. Agenda 2000 - a CAP for the future. European Union. http://europa.eu.int/comm/agriculture/publi/review99/ 08_09_en.pdf, accessed 8 February 2001.

EU, 2001a. Reform of the structural policy-cohesion fund. http:// europa.eu.int/scadplus/leg/en/lvb/160018.htm, accessed 8 February 2001

EU, 2001b. Pre-accession assistance-instrument for structural policies for pre-accession. http://europe.eu.int/comm/enlargement/ pas/envir_transp.htm, accessed 8 February 2001.

EU, 2001c. Energy, environment and sustainable development programme. Fifth (EC) (research) Framework Programme (19982002). http://www.cordis.lu/eesd/home.html, accessed 8 February 2001.

FIG, 1995. Statement on the cadastre. Report prepared for the International Federation of Surveyors by Commission 7 (Cadastre and Land Management). http://www.fig7.org.uk/, accessed 15 August, 2000.

FIG, 1996. Bogor declaration on cadastral reform. Report from United Nations Interregional Meeting of Experts on the Cadastre, Bogor, Indonesia, 18-22 March, A joint initiative of the International Federation of Surveyors (FIG) and the United Nations. http://www.sli.unimelb.edu.au/research/publications/ IPW_publ.html

FIG, 1999. Report of the workshop on land tenure and cadastral infrastructures for sustainable development. Bathurst, Australia. http://www.fig.net/, accessed 5 January 2001.

Niklasz, L., Remetey-Fülöpp, G., Baldwin, R.A., 1996. Land registration in Hungary - strategic plan - the next four years, May 1995-May 1999, Version 2.1.

PHARE, 1998. Technical assistance for reviewing and improving the Slovak cadastral system, Final Report of PHARE Project No. SR9402.02.01.02. 
Riddell, J., Rembold, F., 2000. Social and economic impact of land fragmentation in rural society in selected EU accession countries. Proceedings of the UDMS 2000, Delft University of Technology, The Netherlands, 11-15 September, pp. 13-20.

Sonnenberg, J., 2000. Land consolidation and restitution of property rights: a case study in the Czech Republic, Proceedings of the UDMS 2000, Delft University of Technology, The Netherlands, 11-15 September, pp. 105-112.

Ting, L., Williamson, I., 1999. Cadastral trends: a synthesis. The Australian Surveyor 4 (1), 46-54.

Ting, L., Williamson, I.P., 2001. Land administration and cadastral trends: the impact of the changing humankind-land relationship and major global drivers. The Survey Review, 36, 154-174.

Ting, L., Williamson, I.P., Grant, D., Parker, J.R., 1999. Understanding the evolution of land administration systems in some common law countries. The Survey Review 35 (272), 83-102.

UDMS, 2000. In: Fendel, E.M. (Ed.) Proceedings of the UDMS 2000, 22nd Urban and Regional Data Management Symposium on Land Markets and Land Consolidation in Central Europe "Common Problems - Common Solutions", Delft University of Technology, The Netherlands, 11-15 September (Reviewers Rumor, M., Laurini, R., Rasmussen, J., Jones, K., Bogaerts, T., Fendel, E.M.).

UNECE, 1996. Land administration guidelines. Meeting of Officials on Land Administration, UN Economic Commission for Europe, ECE/HBP/96 Sales No. E.96.II.E.7, ISBN 92-1-116644-6, http:// www.sigov.si $/$ mola/Preview $/$ html/projects.html\#nal, WWW accessed 5 September 1999. MOLA has been upgraded to Working Party status as the UNECE Working Party on Land Administra- tion (WPLA) at http://www.unece.org/env/hs/wpla/welcome.html \par

Wiebe, K.D., Meinzen-Dick, R., 1998. Property rights as policy tools for sustainable development. Land Use Policy 15 (3), 203-215.

Williamson, I.P., 2000. Institutional framework reforms for land administration. Topic Cycle 10, World Bank Land Administration Project-Part C. National Development Planning Agency (BAPPENAS) and National Land Agency, Government of the Republic of Indonesia. http://www.landpolicy.org, accessed 9 August 2000.

Williamson, I.P., 2001. Land administration "best practice"-providing the infrastructure for land policy implementation. Journal of Land Use Policy, in press.

Williamson, I.P., Ting, L., 2001. Land administration and cadastral trends - a framework for re-engineering. Computers, Environment and Urban Systems, 25, 339-366.

Williamson, I.P., Ting, L., Grant, D.M., 2000. The evolving role of land administration in support of sustainable development-a review of the United Nations International Federation of surveyors Bathurst declaration for sustainable development. The Australian Surveyor 44 (2), 126-135.

World Bank, 1999. Proceedings of the International Conference on the Development and Maintenance of Property Rights, The World Bank and the European Union, UN/ECE, Federal Ministry of Justice and Federal Office of Metrology and Survey of the Republic of Austria, Vienna, May 26-29.

Zevenbergen, J., Bogaerts, T., 2000. Alternative approaches for successful cadastral systems. Proceedings of the UDMS 2000, Delft University of Technology, The Netherlands, 11-15 September, pp. 67-76. 